(c) 1991 ISIJ

IIIIIIIIIIIIIIIII!

論 文

チタンの陽極酸化に及ぼす表面状態の影響

IIIIIIIIIIIIIIIII

\author{
北山 司郎 ${ }^{*} \cdot$ 志田 善明*2 ・村山順一郎 $* 3$
}

\title{
Effect of Surface Condition on the Anodizing Behavior of Titanium
}

\author{
Shiroh Kitayama, Yoshiaki Shida and Jun'ichiro Murayama
}

\begin{abstract}
Synopsis :
The influence of surface condition on the anodization coloring behavior of titanium has been studied. It was found that uniform coloring was observed on polished surfaces while multiple coloring was observed on pickled surfaces. From the relationship obtained between crystal orientation of base metal and anodized film thickness, it was concluded that the film growth was faster on prism surfaces and was slower on basal surfaces. It was also confirmed by in-depth analysis of anodized surface on $\mathrm{Ti}$ alloy that the film was of inward growth type.
\end{abstract}

Key words : titanium; nonferrous metal; anodization; surface condition; diffusion; oxidation; surface analysis.

\section{1. 緒言}

陽極酸化は，しばしばバルブ金属と呼ばれる $\mathrm{Al}, \mathrm{Zr}$, $\mathrm{Ti}, \mathrm{Nb}, \mathrm{Ta}, \mathrm{Hf}$ などに適用され，これらの陽極酸化皮 膜はカソード電流は流すがアノード電流は通さない半導 体的な性質がある。陽極酸化で形成される皮膜厚さが約 $300 \mathrm{~nm}$ 以下の場令は, 膜表面で仿射した光と膜一如材界 面で伩射した光との十涉作用で種々の発色を呈する。こ の酸化皮膜厚さ（色）は，電压の制御で比較的唂易に変 化させることができる. チタンの発色に用いることがで きる電解質は多種多様であるが, 塩化物やふっ化物等の 八ロゲンイオンを含む浴液では皮膜破壊を生じやすくな るため利用できない1)とされている.

陽極酸化処理は発色を利用して装飾品, 【芸品に使わ れてきたが, 最近では建築用内外装极，モニュメント等 に用いられている2) 4). また, 酎摩耗性塗料密着性们上 の下地処理 ${ }^{5)}$ や水素吸収防止:手段 ${ }^{6)-8)}$ としても用いら
れている.

チタンの陽極酸化皮膜の厚さ及び組成を検討した

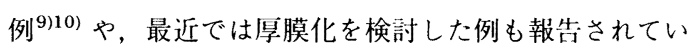
る ${ }^{11)}$ が, 表面状態の影響を報告した例は少ない.そこで, 本報告では下地処理として研磨及びエッチングを採り上 げ，(1)皮膜厚さに及ぼす陽極酸化電压及び下地処理の 影響, ( 2 )陽極酸化挙動（陽極酸化効率, 結晶方位依存 性, 皮膜の成長挙動）について報告する.

\section{2. 実 験 方 法}

\section{$2 \cdot 1$ 供試材}

供試材は 3 種類の純チタン及び 1 種類のチタン命金を 用い, 試験片形状はすべて板状である. 供試材の化学:成 分を Table 1 に示す.

供試材 No. 1 は冷延焼鈍板（厚さ $0.7 \mathrm{~mm}$ ) で陽極酸 化発色に及ぼす前処理条件の影響の検討, 陽極酸化効率 の検討に, 供試材 No. 2 (真空溶解鋳塊より切り出した

Table 1. Chemical compositions (mass \%).

\begin{tabular}{|c|c|c|c|c|c|c|c|c|c|c|}
\hline TP. No. & Specimen & C & $\mathrm{H}$ & $\mathrm{O}$ & $\mathrm{N}$ & $\mathrm{Fe}$ & $\mathrm{Al}$ & Mo & V & $\mathrm{Ti}$ \\
\hline $\begin{array}{l}1 \\
2 \\
3 \\
4\end{array}$ & $\begin{array}{l}\text { Cold rolled } \\
\text { As cast } \\
\text { As hot rolled } \\
\text { As cast }\end{array}$ & $\begin{array}{l}0.008 \\
0.003 \\
0.005 \\
0.007\end{array}$ & $\begin{array}{l}0.0030 \\
0.0005 \\
0.0011 \\
0.0005\end{array}$ & $\begin{array}{l}0.108 \\
0.062 \\
0.310 \\
0.110\end{array}$ & $\begin{array}{l}0.0064 \\
0.0077 \\
0.0060 \\
0.0070\end{array}$ & $\begin{array}{l}0.053 \\
0.070 \\
0.210 \\
0.060\end{array}$ & $\frac{-}{\overline{-}}$ & $\begin{array}{l}\overline{-} \\
\overline{1.10}\end{array}$ & $\frac{-}{E}$ & $\begin{array}{l}\text { Bal. } \\
\text { Bal. } \\
\text { Bal. } \\
\text { Bal. }\end{array}$ \\
\hline
\end{tabular}

昭和 61 年 10 月日本金属学会にて発表 平成 2 年 11 月 9 H受付 (Received Nov. 9, 1990)

* 住龙金属工業(株)未来技術研究所 (Advanced Technology Research Laboratory, Sumitomo Metal Industries, Ltd., 1-8 Fuso-cho Amagasaki 660)

*2 住友金属.L業(株)来泍技術研究所 Ph. D. (Advanced Technology Research Laboratory, Sumitomo Metal Industries, Ltd.)

*3 住金テクノリサーチ(株)表面解析チーム I博（Surface Analysis Section, Sumikin Techno Research Ltd.） 
Table 2. Anodizing condition.

\begin{tabular}{|c|c|}
\hline Electrolyte & $\begin{array}{l}10 \text { vol } \% \mathrm{H}_{3} \mathrm{PO}_{4}+10 \mathrm{~g} / \mathrm{l} \text { Dextrin in distilled } \\
\text { water }\end{array}$ \\
\hline Voltage & $15 \sim 95 \mathrm{~V}$ \\
\hline Counter electrode & $\begin{array}{l}\text { CP titanium sheet or SUS304 stainless } \\
\text { steel sheet }\end{array}$ \\
\hline $\begin{array}{l}\text { Anodizing time } \\
\text { Temperature }\end{array}$ & $\begin{array}{l}30 \sim 180 \mathrm{~s} \\
\mathrm{RT}\end{array}$ \\
\hline
\end{tabular}

Table 3. Surface-finish conditions before anodizing.

\begin{tabular}{c|ll}
\hline TP. No. & \multicolumn{2}{|c}{ Surface-condition } \\
\hline 1 & (1) Wet paper polished & (2) Paper polished and pickled \\
2 & (1) Mirror polished & (2) Mirror polished and pickled \\
3 & (1) Mirror polished & (2) Mirror polished and pickled \\
4 & (1) Mirror polished & (2) Mirror polished and pickled \\
\hline
\end{tabular}

鋳片, 厚さ $5 \mathrm{~mm}$ ）は陽極酸化皮膜厚さに及ぼす電解電 压及びエッチングの影響と, 皮膜厚さと結舀面との関係 の調査に, No. 3 (熱延板, 厚さ $5 \mathrm{~mm}$ ) は陽極酸化に及 ぼす結晶配问の影響の検討に, No. 4 (真空溶解鋳塊よ り切り出した鋳片, 厚さ $5 \mathrm{~mm}$ ) は皮膜成長方向の検討 に用いた。

\section{$2 \cdot 2$ 陽極酸化条件}

電解溶液はりん酸浴を用い, 直流定電压発生装㯰（発 生電圧 0 ～ $125 \mathrm{~V}$, 最大電流 $1.25 \mathrm{~A}$ ) で陽極酸化を行っ た. 単なるりん酸溶液では約 $90 \mathrm{~V} て ゙$ て膜破壊を生じる ので, 皮膜破壊電压を上げるためデキストリンを添加し た $10 \mathrm{vol} \%$ りん酸+ $10 \mathrm{~g} / \mathrm{l}$ デキストリン浴を用いた。陽 極酸化中の対極には通常純チタン板（极厚 $\times$ 幅×長さ： $0.7 \times 100 \times 200(\mathrm{~mm}))$ を用い, 陽極酸化中の皮膜形成 効率を調べる場命のみ SUS304 ステンレス板 $(0.7 \times$ $100 \times 200(\mathrm{~mm}))$ を用いた。陽極酸化条件を Table 2 に, 陽極酸化前のチタン表酳状態を Table 3 に示す。エッ チングは硝ふっ酸水溶液 (3 vol\% $\mathrm{HF}+15$ vol\% $\mathrm{HNO}_{3}$ +82 vol $\% \mathrm{H}_{2} \mathrm{O}$ : 童温)を用いた。

\section{$2 \cdot 3$ 調查方法}

(1) 発色状況の判定

発色状海は目視観祭で, ミクロ組織観祭は光学:顕微鏡 で䘕た。

\section{( 2 )陽極酸化皮膜厚さと皮膜成分の測定}

陽極酸化で形成される皮膜厚さは極めて薄いため, Applied Research Laboratories 社製 IMMA を用いス パッタリング時閆から換算し算出した. IMMAによる 皮膜厚さは，経験上皮膜を表面から厚み力问にスパッ タリングした際の酸素イオン強度の最大值 $\left(O_{p}\right)$ と尘 常值 $\left(\mathrm{O}_{n}\right)$ との差を自然対数の常数 $(e)$ で割った值 $\left(\left(\mathrm{O}_{p}-\mathrm{O}_{n}\right) / e\right)$ の酸素イオン強度となる表面からの距 離（この場令はスパッタリングタイム）とした（Fig. 1

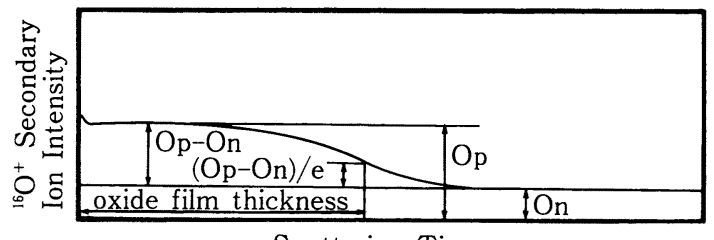

Sputtering Time

$\mathrm{O}_{p}$ : Peak intensity of oxygen $\mathrm{O}_{n}$ : Base intensity of oxygen Fig. 1. Definition of oxide film thickness by IMMA.

参照)。あらかじめ鏡面研磨後陽極酸化したチタンのス パッタリング深さを Rank Tailor Hobson 社製タリス テップ（触針式段差測定器）で測定し，スパッタリング 速度を求め較正データとし，エッチング材の皮膜厚さは IMMA 測定データから決定した.

チタン合金の陽極酸化皮膜の成分分析は，日立製 H-3 型 SIMS を用いて行った。

\section{( 3 ) 結晶配向}

鋳塊の粗大結晶粒の結晶面の決定は, X 線背面ラウ エ法で行った．測定は理学電機製 D-3F 型 X 線回折装 置を用い, タングステンターゲット， $35 \mathrm{~V}, 15 \mathrm{~mA}$ の 条件で, 異なる発色面を内径 $0.5 \mathrm{~mm}$ のコリメーターを 用いて行った.

\section{3. 結果および考察}

\section{$3 \cdot 1$ 発色に及ぼす下地処理の影翌}

チタンを淔流定電圧の条件で陽極酸化すると，急激に 電流が立ち上がった後, 電压が設走電压になると共に電 流は減少し, チタン表面が着色し陽極酸化皮膜が形成さ

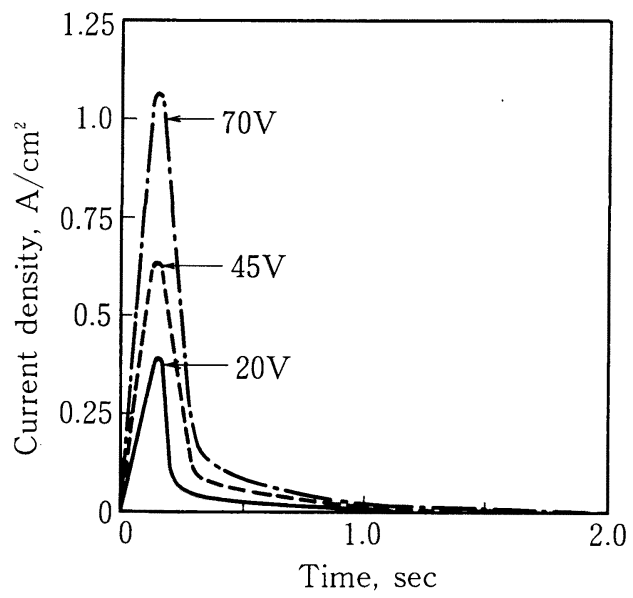

Fig. 2. Initial anodic current change during anodizing (TP. No. 1 : paper polished). 
れるのが観察されアノードピーク電流密度は, 電厈にほ ほ比例した (Fig. 2). 試料 No. 1 の陽極酸化電压によ る発色の変化を Photo. 1 に示す。電流が減少し $10^{-4} \mathrm{~A} / \mathrm{cm}^{2}$ オーダーの微小電流になってからは着色の 変化は認められなかった。

次に硝ふっ酸エッチング後陽極酸化を行うと, 発色研 磨材の様子とは異なっていた。エッチング後陽極酸化し た試料外観をPhoto. 1 に令わせて示す。光学:顕微鏡を 用いてミクロ組織観祭を行うと，研磨酒に陽極酸化した

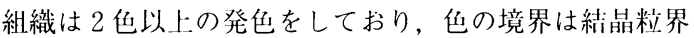
に浴って恋められた（Photo. 2)。ママクロ的に見た場令， 研磨材の発色と異なって見えたのは，ミク口的に見える 色が混令してその中閒色に見えるためと判明した。

研磨材の発色が均一であること, エッチング材の発色 が不均一となることの理由は次のように考えられる。

研磨ままの面は，比較的均一な加丁層で覆われている。 そのため陽極酸化発色は均一となる。一力多結晶である チタンをエッチングすると，異なる結昆面が表面に現れ る。 その際，陽極酸化皮膜の成言が谷易な百では皮膜が 厚くなり，文対に皮膜の成言が容易でない面では皮膜厚 さが薄くなる。そのためエッチング面では多色となる.

\section{$3 \cdot 2$ 陽極酸化皮膜厚さに及ぼす下地処理の影響}

$3 \cdot 1$ で述べた結晶粒ごとの発色の違いを調べるため, 粗大結品粒の鋳片（試料 No. 2) を用いて，同様の陽極 酸化条作で発色を試みたところ，冷延柲を用いたと间様 に鏡涌研磨材では均一発色が，鏡面研磨後エッチング材 は闹…試料の表洦で多色の発色が認められた（Photo. 3). IMMAによる陽極酸化皮膜厚さの測定結果を電压 及び表洦什上げの影響として Fig. 3 に示す。

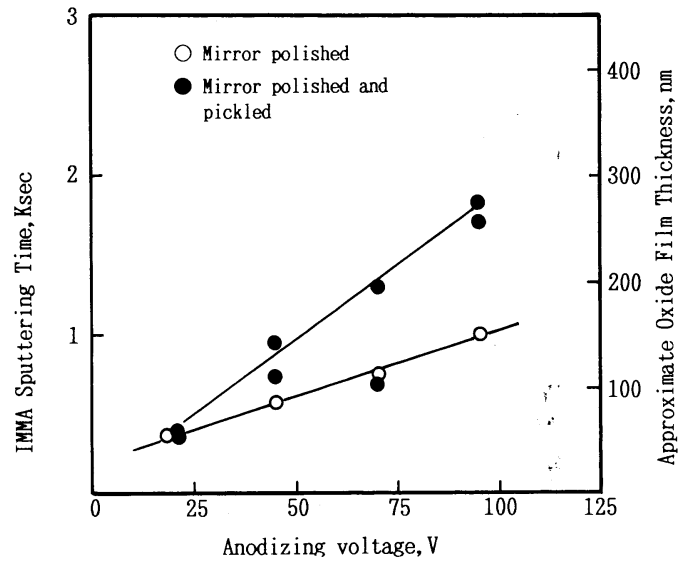

Fig. 3. Effects of anodizing voltage and surface preparations on oxide film thickness (TP. No. 2 : mirror polished).
エッチング後陽極酸化した皮膜厚さは当然ながら結晶 粒（色）によって異なり，しかも鏡面研磨後陽極酸化し た皮膜厚さに対し同等かそれ以上の厚さであった。ッ チング材の最大皮膜厚さと鏡面研磨材の皮膜厚さとの差 は, 電压の上昇と共に増大した。鏡面研磨材の皮膜厚さ は電压と直線関係にあり，エッチング材の最大皮膜厚さ も電压に対し淔線関係を示した。電压 $(V)$ と皮膜厚さ (d) との関係式は以下に示すように，エッチング材の 最大皮膜厚さの電压依存性は鏡面研磨材の約 2 倍の值と なった。

(1)鏡面研磨材

$d=1.27 V+30.35$

(2)エッチング材（最大皮膜厚さ）

$d=2.93 V-2.35$

$d:$ 皮膜厚さ $[\mathrm{nm}]$

$V:$ 電压 $[\mathrm{V}]$

陽極酸化皮膜厚さの電压依存性については $2 \mathrm{~nm} / \mathrm{V}^{3)}$ の報告例があるが，今回得られた鏡面研磨材の電压依你 性はこの値より小さく，エッチング材の最大皮膜厚さの 電压依存性はこの値より大であった。

陽極酸化で得られる色は，干涉色であることを述べた． このことを利用して，今回 IMMA 測是結果から得られ た皮膜厚さの妥当性を検討した。光の十涉は皮膜を通り 皮膜一材界面で仅射した光と皮膜表面で皮射した光と の位相が一致した場合に，その波長に固有の色となって 見える。 その関係から式( 1 )を満足する 1 回皮射の光と の平涉から計算した皮膜厚さと今回の実験結果とを比較 した結果を Fig. 4 に示す. Fig. 4 の結果から今回得た

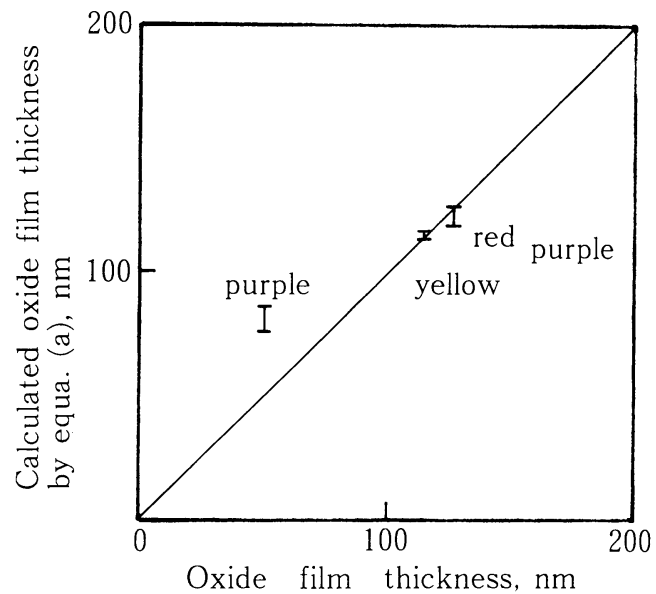

Fig. 4. Corelation between measured oxide film thickness and calculated oxide film thickness by equation (a) (TP. No. 2 : mirror polished). 


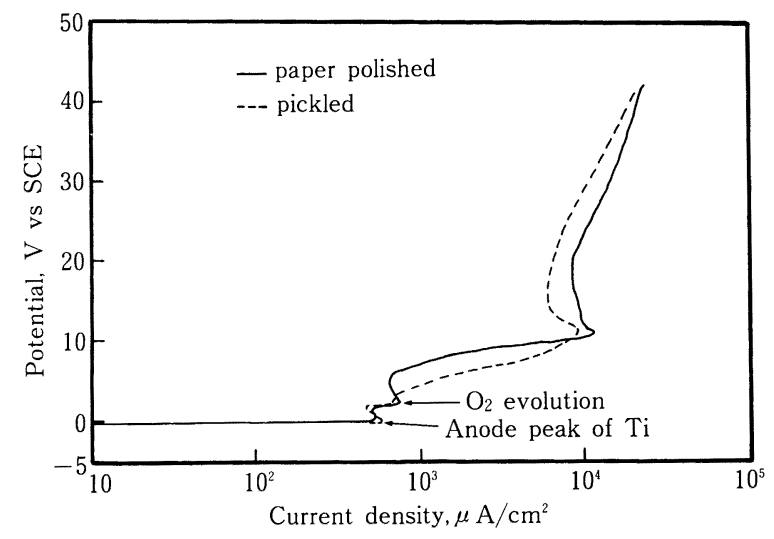

10 vol\% $\mathrm{H}_{3} \mathrm{PO}_{4}+10 \mathrm{~g} / \mathrm{l}$ dextrin $\mathrm{RT}$ Sweep rate $: 0.6 \mathrm{~V} / \mathrm{min}$ Fig. 5. Polarization curves of titanium in phosphoric acid solution.

皮膜厚さはほぼ妥当な値であることが言える.

$m \times(\lambda \times n)=d$

$\lambda:$ 波長 $[\mathrm{nm}]$

$n:$ 屈折率 $[=2.52]$

$d:$ 皮膜厚さ $[\mathrm{nm}]$

$m:$ 整数 $[1,2,3 \cdots \cdots \cdot]$

\section{$3 \cdot 3$ 陽極酸化中の電気化学的測定結果}

陽極酸化は溶液の電気分解で発生する酸素と反応して 生ずるのであるから，チタンの表面状態によって酸素の 発生状態が異なるか否かを調べるため, チタンをりん酸 ナデキストリン溶液中でアノード分極した．分極測定結 果を, Fig. 5 に示す.酸素は理想的には $1.3 \mathrm{~V}$ ( vs. NHE) から発生し始めるが，アノード分極曲線には二つのピー クが認められた．第一のピークはチタンのアノード溶解 を示すピークであり，第二のピークが酸素発生を示す ピークである.エッチング材とペーパ研磨仕上げ材との 酸素発生電位には大きな差は認められなかった。

陽極酸化過程で皮膜が形成された後の, 電流の経時変 化を Fig. 6 に示す.アノード電流ピークは陽極酸化電 圧にほほ比例して増加した（Fig. 2 参照）が, 大半の 皮膜が形成された後の電流の減衰は, 電圧によらずほほ 同様に時間の対数に対し直線的であった。

次に, チタンの陽極酸化中のチタンの皮膜形成効率を 調べた. 陽極酸化過程の反応は, 以下の反応によって進 行すると考えられる.

$\mathrm{Ti}$ の溶解反応

$\mathrm{Ti} \rightarrow \mathrm{Ti}^{3+}+3 e$ or $\mathrm{Ti} \rightarrow \mathrm{Ti}^{2+}+2 e$

$\mathrm{Ti}$ の酸化皮膜形成反応

$\mathrm{Ti}+2 \mathrm{H}_{2} \mathrm{O} \rightarrow \mathrm{TiO}_{2}+4 \mathrm{H}^{+}+4 e$

酸化皮膜形成反応の効率を見るために，印加電圧と試 料の表面状態をパラメーターに陽極酸化中のチタン溶出

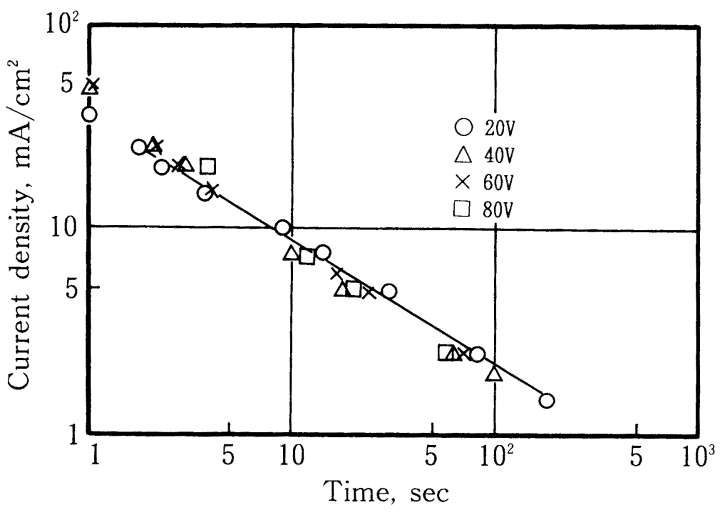

Fig. 6. Anodic current change during anodizing (TP. No. 2 : mirror polished).

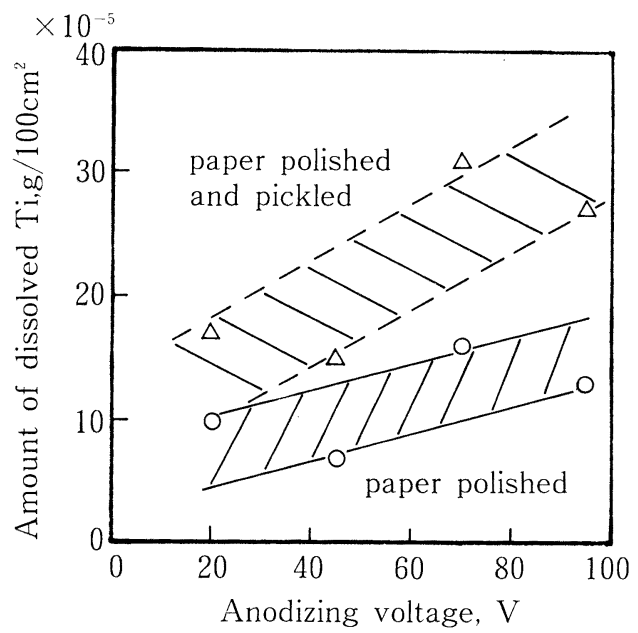

Fig. 7. Amount of dissolved Ti during anodizing.

量を測定した。結果を Fig. 7 に示す. 陽極酸化電圧の 増加と共に溶出量は増加する傾向となった。 
次に Fig. 7 の結果を用いて，チタンの陽極酸化皮膜 形成効率を算出した。陽極では( 2$)$ 及び( 3 )式の反応が 起こる.すなわちち理想的に( 3 )のみが起こるとすると 4 ファラデーで 1 モルの陽極酸化皮膜が形成されること になり,陽極酸化中に通電した電気量を測定することで, 理想条件での酸化皮膜厚さは (4)式で算出される。千多 ン薄膜上に形成した陽極酸化皮膜を TEM 観察すると， 低電圧ではブロードなリングが認められたが電圧 $70 \mathrm{~V}$ で生成した皮膜は多結晶を示すリングパターンのみが認 められ (Photo. 4 参照), 皮膜と素地との特定の方位関 係は認められなかった， $70 \mathrm{~V} て ゙$ て形成された皮膜はアナ ターゼ型と同定されたので, 皮膜の密度はアナターゼの 值を用いた。

$d=(M / \rho) \times(C / 4 F)$

$d:$ 皮膜厚さ $[\mathrm{cm}]$

$M: \mathrm{TiO}_{2} 1$ モル重量 $[48+16 \times 2=80 \mathrm{~g} / \mathrm{mol}]$

$\rho: \mathrm{TiO}_{2}$ (アナターゼ型) の密度 $\left[=3.9 \mathrm{~g} / \mathrm{cm}^{3}{ }^{12}\right.$ )

$C:$ 陽極酸化に要した電気量

$F:$ ファラデー定数 $[=96500 \mathrm{C}]$

溶出量と陽極酸化後の重量増とを加えた值を試験片表

\begin{tabular}{|l|c|c|c|c|}
\hline \multirow{2}{*}{} & \multicolumn{4}{|c|}{ Anodizing voltage, V } \\
\cline { 2 - 5 } & 20 & 45 & 70 & 95 \\
\hline $\begin{array}{l}\text { Paper } \\
\text { polished }\end{array}$ & & & & \\
\hline Pickled & & & & \\
& & & & \\
\hline
\end{tabular}

Photo. 1. Coloring behavior of cold rolled $\mathrm{Ti}$ sheet (TP. No. 1).

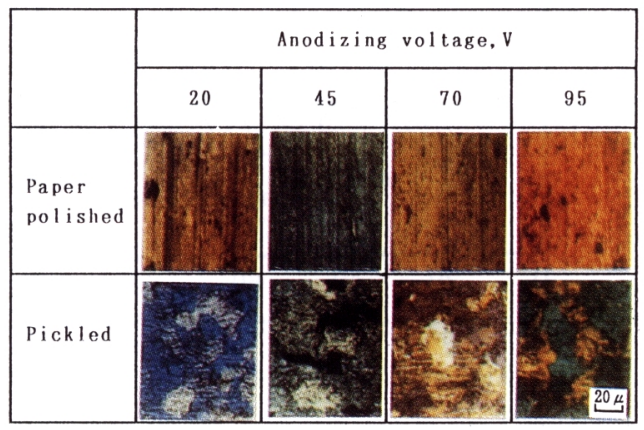

Photo. 2. Color micrographs of anodized cold rolled Ti sheet (TP. No. 1).
面に生成した酸化皮膜中の酸素の重量とし，この酸素重 量から得られる皮膜厚さと(4)式に通電電気量を代入し て得られる理想皮膜重量との比率を皮膜形成効率として 試算した。計算結果を Table 4 に示す。エッチング材 の皮膜形成効率は 52 - 89\% と研磨材の形成効率の 32 50\%より大であった。

\section{$3 \cdot 4$ 陽極酸化皮膜厚さ（発色）に及ぼす結晶配向の影 䡬}

$3 \cdot 1$ 及び $3 \cdot 2$ 項でエッチング後陽極酸化すると, 酸化 皮膜の成長が結晶粒によって異なることを明らかにした が，その原因は結晶配向の影響と推定された。そこで, 粗大粒の鋳片を 45 95 V で陽極酸化し, 酸化皮膜厚さ の厚い面及び薄い面について，X 線背面ラウエ法で結 晶面を決定することを試みた。

背面ラウエ解析結果を Fig. 8 に示す. 陽極酸化皮膜 厚さが薄くなる面は, 皮膜厚さの厚い面に比べ底面に近 い面であることが判明した。

さらに，熱延板を用い，底面極及び錘面極が分散して いる圧延面, 及び柱面極が集積している圧延方向及び圧

\begin{tabular}{|l|c|c|c|c|}
\hline \multirow{2}{*}{} & \multicolumn{4}{|c|}{ Anodizing voltage, $V$} \\
\cline { 2 - 5 } & 20 & 45 & 70 & 95 \\
\hline $\begin{array}{l}\text { As mirr- } \\
\text { or poli- } \\
\text { shed }\end{array}$ & 0 & & 0 & 0 \\
\hline $\begin{array}{l}\text { Mirror } \\
\text { polished } \\
\text { and } \\
\text { pickled }\end{array}$ & $\mathbf{O}^{\circ}$ & $\mathbf{C}$ & 0 & \\
\hline
\end{tabular}

Photo. 3. Appearances of as cast $\mathrm{Ti}$ anordizing (TP. No. 2).

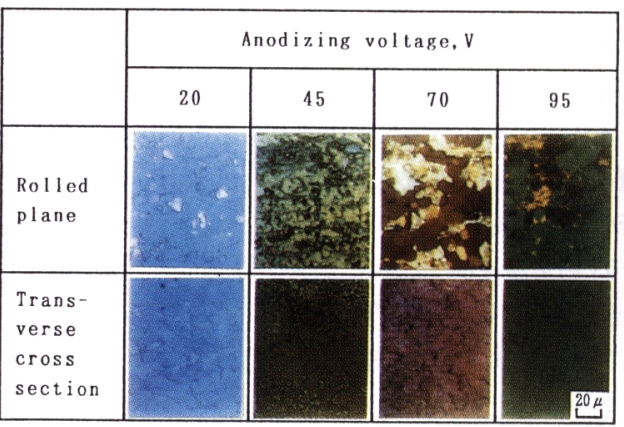

Photo. 5. Color micrographs of as hot rolled Ti plate by anodizing (TP. No. 3). 

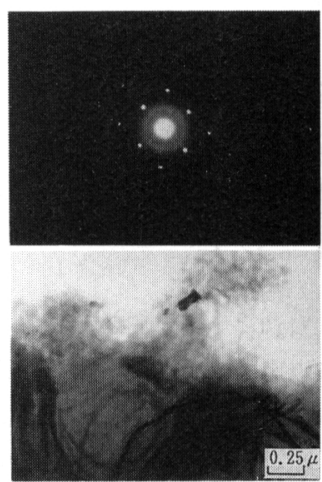

$15 \mathrm{~V}$
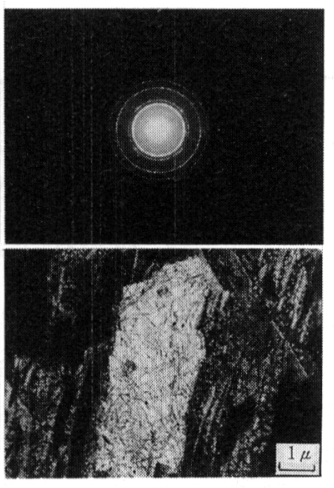

$70 \mathrm{~V}$

Photo. 4. Electron micrographs and diffraction patterns of anodized Ti oxide film (TP. No. 1).

Table 4. Anodizing efficiency (\%) of $\mathrm{Ti}$ in phosphoric acid + dextrin solution.

\begin{tabular}{c|cc}
\hline Anodizing voltage [V] & Paper polished & Pickled \\
\hline 20 & 32 & 92 \\
45 & 46 & 52 \\
70 & 50 & 73 \\
95 & 48 & 89 \\
\hline
\end{tabular}
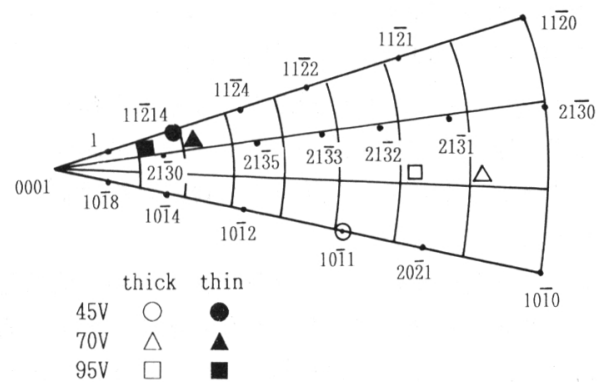

Fig. 8. Effect of crystallographic orientation on anodized $\mathrm{Ti}$ oxide film thickness (results of $\mathrm{X}$-ray raue method analysis of TP. No. 2).

延面に直角な断面をそれぞれエッチング後陽極酸化し た. 熱延板の集合組織を Fig. 9 に, 陽極酸化後のミク 口組織を Photo. 5 に示す. 底面及び錘面極が分散して いる圧延面の発色は多色となっているのに対し，柱面極 が集積している压延方向及び圧延面に直角な面の結晶粒 はすべて同一の発色で, しかも圧延面の厚い皮膜厚さの 発色と同一色となった。この実験事実から, 柱面は発色 が容易な面であることが確認された。

\section{$3 \cdot 5$ チタン合金の陽極酸化皮膜の元素分析結果}

$\mathrm{Ti}-8 \mathrm{Al}-1 \mathrm{Mo}^{-}-1 \mathrm{~V}$ 合金を陽極酸化し, その皮膜を SIMS で元素分析した. 陽極酸化皮膜の成分の分析結果
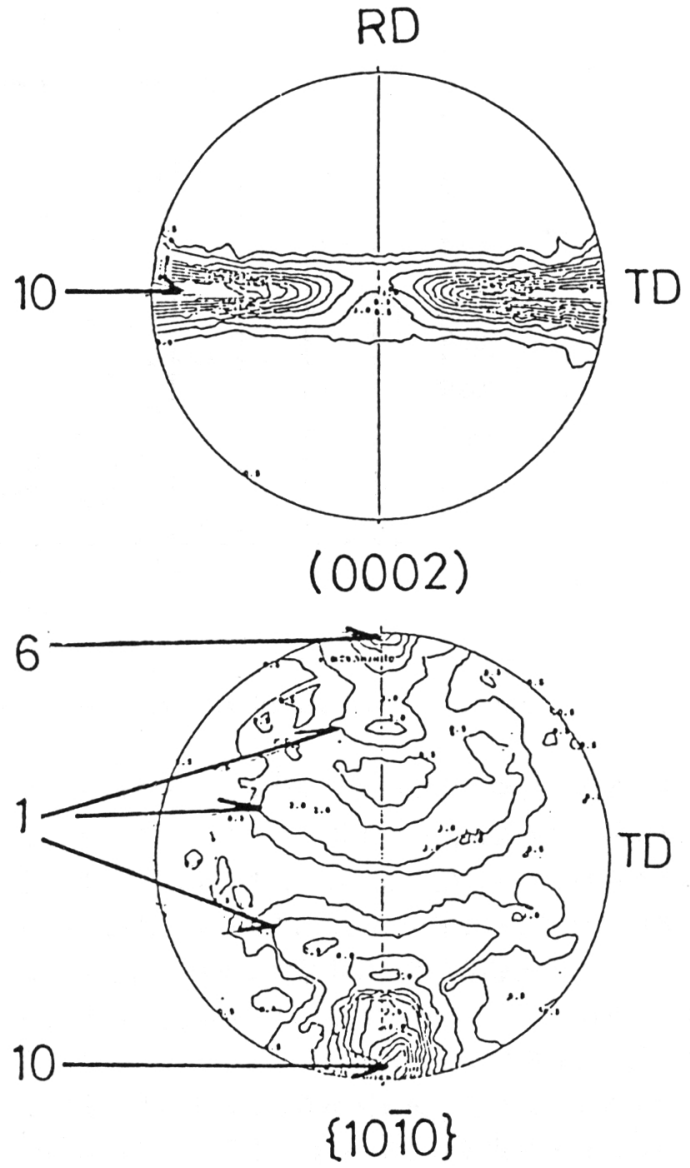

Fig. 9. Pole figures of hot rolled plate (No. 3) (numbers in figure : indication of diffraction strength).

を Fig. 10 に示す. 皮膜表面部を除き，元素の皮膜中の 分布を見ると $\mathrm{O}, \mathrm{Al}, \mathrm{Ti}, \mathrm{V}$ 及び Mo の 2 次イオン強 度はほほ一定であった。

\section{4. 考察}

陽極酸化皮膜の成長方向と, 成長の律速過程について 検討した結果を述べる。

陽極酸化皮膜の成長方向を，3.5 項の $\mathrm{Ti}^{-}-8 \mathrm{Al}^{-}-1 \mathrm{Mo}^{-}$ $1 \mathrm{~V}$ の元素分析結果をもとに考察する. 仮に皮膜の成 長が外方成長であれば，金属成分の濃度分布は乱れるか 皮膜一奶材界面から皮膜表面に向かって濃度勾配が認め られるはずであるが，ほほ一定であったことから皮膜の 大半は内方成長型と考えられ，千タンの陽極酸化皮膜の 成長は酸素が皮膜内を内方にイオン移動することによる と結論できる。 


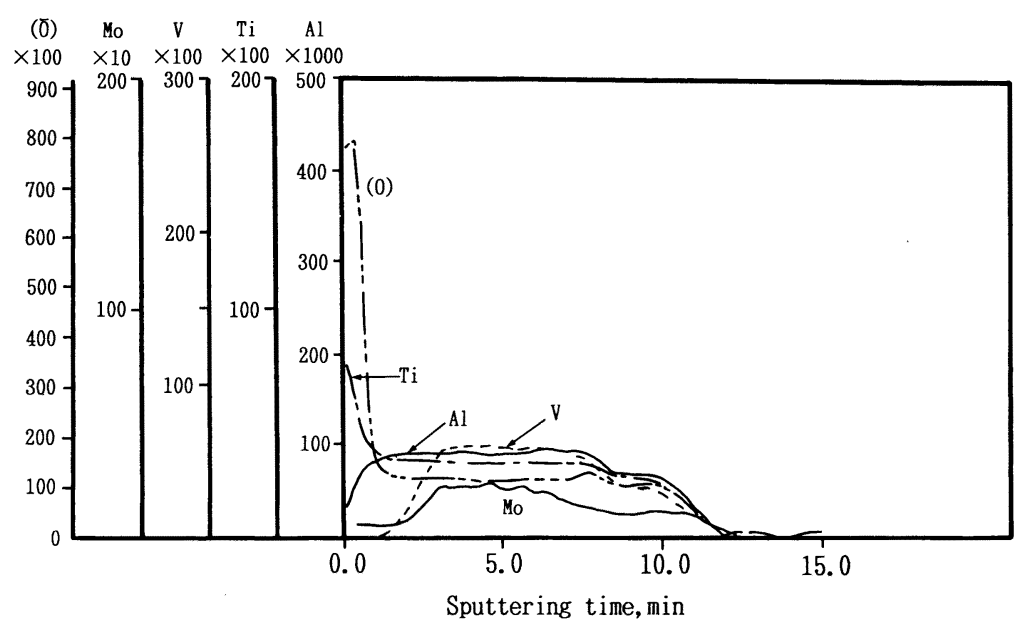

$\mathrm{N}_{2}{ }^{+} 15 \mathrm{kV} \quad 100 \mathrm{nA}$ Sweep area : $4 \%$

Fig. 10. Results of titanium oxide film analysis by SIMS (TP. No. $4:$ mirror polished).

また生成した酸化皮膜は結晶面によって厚みの恭なる ことが確認されたが，その不均一が生じるためには拡散 の異方性がどこかに生ずることが必要である．まず，陽 極酸化で生成した皮膜であるが Photo. 4 の結果から明 らかなように低電压の場命は非晶質であり, 高電圧の場 命は $\mathrm{TiO}_{2}$ (アナターゼ) であった．非晶質では皮膜内 に拡散の方向性はないと考えられ，アナターゼの結晶構 造は正方晶であり若十異方性があると言えるが, 生成し ている陽極酸化皮膜は Photo. 4 の結果から多結晶でラ ンダム方位であり, 皮膜は素地と特定の方位関係なく成 長していると考えられる。このように $\mathrm{TiO}_{2}$ により拡 散の買方性が生ずるとは考えにくい，一方，金属素地は 六方晶であり明らかに拡散の異方性が予想される。 VYKNODETS $ら^{13)}$ は Ti 単結晶上に陽極酸化皮膜を形成さ せた後, 加熱拡散させて結晶方位と酸素の拡散速度との 関係を求めた結果, $\mathrm{c}$ 軸に平行な拡散速度 $\left(D c_{D}\right)$ と $\mathrm{c}$ 軸に垂直な拡散速度 $\left(D c_{O}\right)$ との比 $D c_{D} / D c_{O}$ は 0.88 と なり, $\mathrm{c}$ 軸に平行な酸素の拡散速度が遅いことを報告し ている.これは高温 $\left(560 \sim 610^{\circ} \mathrm{C}\right)$ での結果であり， 陽極酸化のような低温ではさらに異方性が生ずることも 予想される。したがって異方性の原因は素地金属中への 酸素の拡散によると考えると結果をよく説明できる，従 来, 高温下でのルチル型 $\mathrm{TiO}_{2}$ の成長は, $\mathrm{TiO}_{2}$ 中の格 子欠陥と関係があり酸素イオン空孔の拡散に律速される と一般に考えられている。 しかしながら，陽極酸化皮膜 の成長は低温でしかも皮膜中に高い電位勾配が生じてお ク，ルチル型 $\mathrm{TiO}_{2}$ の成長と同様の考えが適用できるか という点については検討が必要である. Fig. 2 からも
分かるように大半の皮膜厚さは $1 \mathrm{~s}$ 以内に生成する. 恐 らく大きな電位勾配下で酸素イオンの内方拡散が極めて 早く生じているものと考えられる.すなわち，金属中の 酸素拡散の方が皮膜中より遅いことは十分考えられる. 金属素地に酸素が吸収されているのが早いほど酸化物/ 金属界面の内方移動は早く, 皮膜成長が促進されると いったメカニズムが一つの推論として考えられる. しか し上記の考察は推定の議論が多く, 一つの叮能性を示唆 するにすぎないと言え，今後さらに確証と検討が必要と 考えられる.

なお，電流効率がエッチング材で大きいのも酸素発生 が少ないことを意味しており，酸化物成長が大きい部分 があることで酸素が有効に材料中に取り込まれることと 関係しているのかもしれない.

\section{5. 結言}

純チタン及びチタン合金を用いて陽極酸化を行い，陽 極酸化及び陽極酸化挙動に及ぼす下地処理の影響として 研磨及びエッチングを取り上げて検討した結果, 以下の ことが判明した。

(1)多結晶チタン表面を鏡面あるいはペーパー研磨後 陽極酸化すると均一発色となるが, エッチング後行うと 結晶粒によって色が異なる.

( 2 )研磨面に形成される陽極酸化皮膜及びエッチング 面に形成される最大皮膜厚さは, 印加直流電圧に対して 直線的に増加し, 後者に生成する最大皮膜厚さの電圧依 存性は前者の約 2 倍となる.

( 3 )エッチング面で形成される陽極酸化皮膜厚さは表 
面結晶粒の方位により異なり，同一陽極酸化条件でも柱 面上に形成される皮膜厚さは底面上のそれよりも厚い.

(4)陽極酸化皮膜は皮膜厚さが薄い場合はアモルファ ス，厚い場合は多結晶のアナターゼ型となっており，大 半が内方成長型であることが確認された。

\section{6. おわに}

本実験の遂行は，当時住友金属工業(株)総合技術研究 所非鉄材料研究公（現：小倉製鉄所分塊工場勤務）の向 井一範氏の協力に負うところ大であり，ここに謝意を表 するしだいである.

\section{文献}

1) A. Aladjem: J. Mat. Sci., 8 (1973), p. 688

2 ）長瀬邦大: 金属, 58 (1988), p. 38

3 ) 押山道大: アルミニウム研究会誌 (1986), p. 7
4 ）山口英俊, 佐藤広士: 表面技術, 40 (1989), p. 64

5 ) 電気化学便覧第 4 版（電気化学協会編）(1985), p. 370 [丸善]

6 ) R. L. JACOBS and J. A. MCMASTER: Materials Performance, 11 (1972), p. 33

7 ) J. A. MCMASTER: Materials Performance, 20 (1979), p. 28

8 ) W. J. NEIL: Materials Performance, 21 (1980), p. 28

9 ) P. C. S. HAYFIELD: Proc. Second International Conference on Titanium (1976), p. 2405

10) E. A. Garcia and C. O. De Gonzalez: Proc. Sixth International Conference on Titanium (1988), p. 1823

11）広地通明, 松永英之, 大中 隆, 山田喆久大, 伊東征司, 田中雅美: 表面処理技術協会第 76 回講演大会要旨集 (1987), p. 120

12）坂本正志: セラミックス, 21 (1986), p. 312

13) $V$. B. Vykhodets, $S$. M. Klotsman, $T$. Ye Kurennykh, L. D. Kurmayeva, $A$. D. Levin, $V$. A. Pavlov, $M$. $A$. Plekhanov and $L$. V. Smirnov: Phys. Met. Metall., 63 (1987), p. 127 